J. 59:240-243.

Timmons, D.R., R.F. Holt, and J.J. Latterell. 1970. Leaching of crop residues as a source of nutrients in surface runoff water. Water Resour. Res. 6:1367-1375.

Tossell, R.W., W.T. Dickinson, R.P. Rudra, and G.J. Wall. 1987. A port- able rainfall simulator. Can. Agric. Eng. 29:155-162.

Tukey, H.B. 1971. Leaching of substances from plants. p. $67-80$. ogy of leaf surface microorganisms. Academic Press, New Ecol.

White, E.M. 1973. Water leachable nutrients from frozen or dried rie vegetation. J. Environ. Qual. 2:104-107.

\title{
Hycrest Crested Wheatgrass Accelerates the Degradation of Pentachlorophenol in Soil
}

\author{
Ari M. Ferro,* Ronald C. Sims, and Bruce Bugbee
}

\begin{abstract}
We investigated the effects of vegetation on the fate of pentachlorophenol (PCP) in soil using a novel high-flow sealed test system. Pentachlorophenol has been widely used as a wood preservative, and this highly toxic biocide contaminates soil and ground water at many sites. Although plants are known to accelerate the rates of degradation of certain soil contaminants, this approach has not been thoroughly investigated for PCP. The fate of $\left[{ }^{14} \mathrm{C}\right] \mathrm{PCP}$, added to soil at a concentration of 100 $\mathrm{mg} / \mathrm{kg}$, was compared in three unplanted and three planted systems. The plant used was Hycrest, a perennial, drought-tolerant cultivar of crested wheatgrass [Agropyron desertorum (Fischer ex Link) Schultes]. The flowthrough test system allowed us to maintain a budget for ${ }^{14} \mathrm{C}$-label as well as monitor mineralization (breakdown to ${ }^{14} \mathrm{CO}_{2}$ ) and volatilization of the test compound in a 155-d trial. In the unplanted systems, an average of $88 \%$ of the total radiolabel remained in the soil and leachate and only $6 \%$ was mineralized. In the planted systems, $33 \%$ of the radiolabel remained in the soil plus leachate, $22 \%$ was mineralized, and $36 \%$ was associated with plant tissue $(21 \%$ with the root fraction and $15 \%$ with shoots). Mineralization rates were $23.1 \mathrm{mg}$ PCP mineralized $\mathrm{kg}^{-1}$ soil in $20 \mathrm{wk}$ in the planted system, and for the unplanted system $6.6 \mathrm{mg}$ PCP kg-1 soil for the same time period. Similar amounts of volatile organic material were generated in the two systems (1.5\%). Results indicated that establishing crested wheatgrass on PCP-contaminated surface soils may accelerate the removal of the contaminant.
\end{abstract}

$\mathrm{T}$ HE WIDESPREAD USE of PCP, especially as a wood preservative, has led inevitably to soil contamination. This highly toxic compound, which has been used as a fungicide, insecticide, herbicide, and disinfectant, can cause serious environmental problems (Rao, 1978), and is on the USEPA's list of priority toxic pollutants (Sittig, 1981, p. 525-526). At many contaminated sites, such as the soil around wood treatment plants, PCP and other chlorophenol derivatives can persist for years and may lead to ground water contamination (Valo et al., 1984; Kitunen et al.,

\footnotetext{
A.M. Ferro, Utah Water Research Laboratory; R.C. Sims, Dep. of Civil and Environmental Engineering; B. Bugbee, Dep. of Plants, Soils, and Biometeorology, Utah State Univ., Logan, UT, 84322. Current address for A.M. Ferro is Dep. of Cellular, Viral, and Molecular Biology, 5C334 Medical Center, Univ. of Utah, Salt Lake City, UT 84132. Financial support for this study was provided by Union Carbide Corporation and by Dynamac Corporation, Robert S. Kerr Environmental Research Laboratory, Ada, OK, as subcontracted by the U.S. Environmental Protection Agency, RSKERL. Support was also provided by the USGS 104 Program and by the Utah Agric. Exp. Stn., Utah State Univ., Logan, UT, 84322. Approved as Journal Paper no. 4448. This report has not had Union Carbide, Dynamac, or USEPA peer review and policy review and does not necessarily reflect the views of those agencies. Received 21 Apr. 1993. *Corresponding author.
}

Published in J. Environ. Qual. 23:272-279 (1994).
1987). There are reports, however, that $P C P$ is readily biodegraded in soil (Bellin et al., 1990). The recalcitrance of PCP at some sites may be due to a variety of factors such as toxic levels of various substances, unfavorable soi conditions, or to a lack of microorganisms with the necessary degradative capabilities (Bellin et al., 1990; Middeldorp et al., 1990; Seech et al., 1991). Bacteria that can metabolize PCP have been isolated from soil (Engelhardt et al., 1986), and one approach to bioremediation has been the inoculation of PCP-contaminated soil with such microorganisms (Edgehill and Finn, 1983; Crawford and Mohn, 1985; Middeldorp et al., 1990). Such schemes are frequently unsuccessful since the introduced microorganisms rarely survive and colonize the complex soil environment (Stroo, 1992).

Another possible approach, which has received comparatively little attention, involves planting vegetation on contaminated soil. Comparisons of planted and unplanted soils have shown increased rates of mineralization of insecticides (Hsu and Bartha, 1979; Reddy and Sethunathan, 1983) and surfactants (Federle and Schwab, 1989), and a greater extent of polyaromatic hydrocarbon (PAH) disappearance (Aprill and Sims, 1990) in planted systems. Other studies have shown that rhizosphere soil, that is, the soil closely associated with the plant root, has greater biodegradative capabilities than unplanted soil (Sandmann and Loos, 1984; Lappin et al., 1985; Walton and Anderson, 1990). There are higher numbers of microorganisms in rhizosphere soil than in unplanted soil, as well as a selective enrichment for certain species (Rovira and Davey, 1974). One reason for this proliferation is plant-root exudation. Up to $20 \%$ of the plant's photosynthate is secreted into the soil as a variety of readily metabolizable organic compounds (Lynch, 1982). Moreover, plants themselves can take up and transform many anthropogenic organic compounds (Edwards, 1986; Topp et al., 1986; Ryan et al., 1988).

Plant uptake of PCP from soil is influenced by a variety of factors, including the concentration of PCP itself. At low levels of the compound (less than $\approx 10 \mathrm{mg} \mathrm{kg}^{-1}$ soil), little PCP is available for plant uptake because it is rapidly degraded by soil microorganisms (Bellin and O'Connor, 1990). Microbial reductive and hydrolytic dechlorination of PCP yield $\mathrm{Cl}^{-}$and intermediates, including ch

Abbreviations: PCP, pentachlorophenol; PAH, polyaromatic hydrocarbon: $\mathrm{CEC}$, cation-exchange capacity; SD, standard deviation; $\mathrm{BCF}$, bioc tration factor. 
nated para-hydroquinones, with further catabolism leading to the formation of insoluble humic complexes as well as ring fission products. These latter compounds fuel central metabolic pathways yielding $\mathrm{CO}_{2}$ and microbial biomass (Steiert and Crawford, 1985; Engelhardt et al., 1986). At higher levels of PCP, many soil microbes succumb to the toxic effects of the chemical (Klecka and Maier, 1985; Ravanel and Tissut, 1986; Ruckdeschel et al., 1987; Yokoyama et al., 1988; Lamar et al., 1990b), and more PCP is available for plant uptake. For example, Weiss et al. (1982) reported that rice (Oryza sativa L.) plants grown for $7.5 \mathrm{mo}$ on soil containing $\left[{ }^{14} \mathrm{C}\right] \mathrm{PCP}\left(172 \mathrm{mg} \mathrm{kg}{ }^{-1}\right)$ took up $12.9 \%$ of the applied radiolabeled $\mathrm{C}$, which was distributed between roots (5.2\%) and shoots (7.7\%). Studies with a variety of other plants (Scheunert et al., 1986; Topp et al., 1986) including wheat (Triticum aestivum L.; Langebartels and Harms, 1985), using $\left[{ }^{14} \mathrm{C}\right] \mathrm{PCP}$, have also demonstrated uptake of radiolabeled $\mathrm{C}$.

Plant uptake of PCP and its metabolites is certainly not unique. A wide variety of organic chemicals, when added to soil, can be taken up by plants (Briggs et al., 1982; Topp et al., 1986). Depending on the content of soil organic matter, plant uptake is maximal for compounds with values of $\log K_{\text {ow }}=1$ to 2 ( $K_{\text {ow }}$, octanol-water partition coefficient; Ryan et al., 1988). Translocation from roots to shoots is also optimal for chemicals with $\log K_{\text {ow }}=1$ to 2, and translocation may increase with transpiration (McFarlane et al., 1987). Removal of soil water by transpiration may also induce the movement, by unsaturated flow, of organic compounds dissolved in the soil water (water moves by unsaturated flow from wetter to drier areas in soil). This mass transport process may draw contaminants to the plants from areas outside the root zone, making them available for uptake.

The weakly acidic nature of PCP $(\mathrm{pKa}=4.8 ; \mathrm{pKa}$, negative logarithm of the acidity constant; Schellenberg et al., 1984) influences its availability for plant uptake. Under neutral or alkaline soil conditions, the predominant form of the chemical is the phenolate anion. Although the phenolate is hydrophobic (at $\mathrm{pH}=7.2, \log K_{\mathrm{ow}}=3.3$; Kaiser and Valdmanis, 1982) and still has some affinity for soil organic matter (Schellenberg et al., 1984), it is probably more available for plant uptake than is the protonated free acid form of PCP $\left(\log K_{\text {ow }}=5.2\right)$ which is strongly sorbed by soil organic matter (Schellenberg et al., 1984; Bellin and O'Connor, 1990). The affinity of the phenolate anion for organic matter retards the mobility of PCP in soil, even under neutral and alkaline conditions (Johnson et al., 1985), so that at many contaminated sites, the compound remains for long periods well within the root zone of plants (Kitunen et al., 1987).

Studies using whole plants have suggested PCP biotransformation, but microbial contamination in such systems often makes it difficult to distinguish between plant and bacterial or fungal metabolism (Haque et al., 1978; Weiss et al., 1982; Casterline et al., 1985). More definitive evicell for plant metabolism of PCP has come from plant cell culture. For example, in axenic cell suspension cultures of wheat, $\left[{ }^{14} \mathrm{C}\right] \mathrm{PCP}$ was converted into polar glucocomplonyl glucosides, and non-extractable covalent complexes with lignin and hemicellulose (Scheel et al.,
1984; Langebartels and Harms, 1985; Schmitt et al., 1985; Harms and Langebartels, 1986). Tetrachlorocatechol was the major PCP metabolite of both the polar and insoluble fractions, with minor amounts of tetrachlorohydroquinone and unmodified PCP (Schäfer and Sandermann, 1988). High recoveries of radiolabel in the various fractions indicated that there was negligible mineralization of $\left[{ }^{14} \mathrm{C}\right] \mathrm{PCP}$ to ${ }^{14} \mathrm{CO}_{2}$ (Sandermann et al., 1984).

This study tested the hypothesis that plants accelerate the removal of PCP present in soil as a contaminant. We compared rates of mineralization of $\left[{ }^{14} \mathrm{C}\right] \mathrm{PCP}$ in planted and unplanted soil, and also measured uptake of ${ }^{14} \mathrm{C}$-label by the plants. The plant used in the study was Hycrest, a cultivar of crested wheatgrass. Grasses, with their deep fibrous root systems, have several advantages over other types of vegetation as a bioremediation tool (Aprill and Sims, 1990). A novel high-flow sealed test system was developed for this investigation that allowed us to maintain a budget for the ${ }^{14} \mathrm{C}$-labeled material and at the same time remove transpirational water vapor and supply $\mathrm{CO}_{2}$ to the actively growing plants. Both mineralization and volatilization of the test compound could be measured by our flowthrough system, since the rapid flux of air through the system minimized photosynthetic fixation of ${ }^{14} \mathrm{CO}_{2}$ and foliar uptake of ${ }^{14} \mathrm{C}$-labeled volatile organic material. We conducted preliminary studies using $\left[{ }^{14} \mathrm{C}\right]$ phenanthrene to check the performance of our flow-through system.

\section{MATERIALS AND METHODS}

\section{Flow-Through System}

A single module of the system, shown diagrammatically in Fig. 1, consisted of planted or unplanted soil covered with a glass bell jar ( 52 by $6.5 \mathrm{~cm})$, through which passed a continuous stream of air (flow rate $=1 \mathrm{~L} \mathrm{~min}^{-1}$ ). Six modules were operated simultaneously, three each for the planted and unplanted systems (Experimental Design).

Radiolabeled $\left({ }^{14} \mathrm{C}\right)$ compounds were added to the soil, and plants were started from seed at the beginning of a trial. Bell jars stood in a growth chamber, and plants (or soil controls) were kept at $23 \pm 1{ }^{\circ} \mathrm{C}$, with a $16 \mathrm{~h}$ photoperiod (photosynthetic photon flux density $=350 \mu \mathrm{mol} \mathrm{m} \mathrm{m}^{-2} \mathrm{~s}^{-1}$ ). Radiation and photoperiod influence the release of organic compounds from plant roots (Whipps and Lynch, 1986), which are substrates for microbial growth, and were therefore crucial factors in this study.

The design of the flow-through system involved the following factors:

1. Assessment of the environmental fate of the ${ }^{14} \mathrm{C}$-label required that we measure radioactivity in soil, plant tissue, and leachate as well as in $\mathrm{CO}_{2}$ and volatile organic compounds.

2. A rapid flow of dry air through the bell jars was necessary to remove transpirational water vapor as well as ${ }^{14} \mathrm{C}$ labeled volatile organic material and ${ }^{14} \mathrm{CO}_{2}$ resulting from mineralization of the test compound. Rapid removal of radiolabeled material minimized its uptake by the plant leaves. Large plants transpired $\approx 20 \mathrm{~mL}$ of water per day.

3. The loss of volatilized ${ }^{14} \mathrm{C}$-label from the system was minimized in order to maintain a budget for the radiolabel. Leaks were reduced by keeping the pressure in the bell jars close to atmospheric pressure $\left( \pm 10 \mathrm{~mm} \mathrm{H}_{2} \mathrm{O}\right.$ column). The bell jars were caulked to glass plates, and this seal was the most likely place in the system for air leaks. 


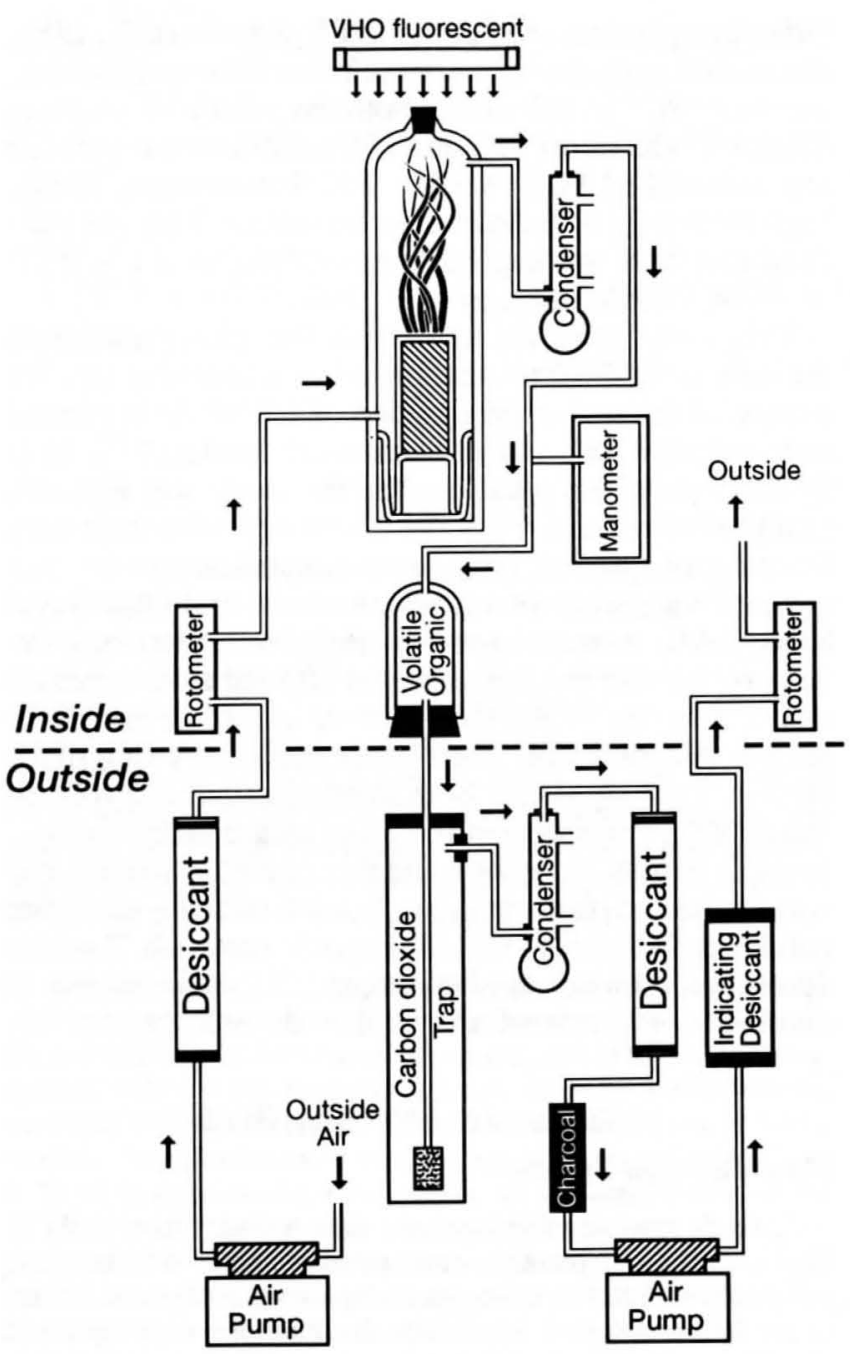

Fig. 1. Flow-through system. A single module is shown. The system employed six modules, three each for the planted (experimental) and unplanted (control) treatments. Arrows indicate the direction of the flow of air through the system $\left(1 \mathrm{~L} \mathrm{~min}^{-1}\right)$. The dotted line indicates components that were either inside or outside of the growth chamber. Radiation in the growth chamber was provided by very high output (VHO) fluorescent lights.

The low pressure-differential in the bell jars was achieved by pumping air into and out of the jars. Flow-rates from the pumps were matched using pairs of rotometers (Fig. 1) and pressure in the bell jars was monitored using manometers. Transpirational water vapor in the air effluent from the bell jars was removed with water-jacketed condensers. The air then passed over traps to remove volatile organic compounds (polyurethane foam diSPo Plugs, obtained from Baxter Diagnostics; Huckins et al., 1984) and $\mathrm{CO}_{2}$ traps containing monoethanolamine. At intervals during a trial, radiolabel accumulating in the $\mathrm{CO}_{2}$ traps was measured to obtain a time-course for mineralization. An infrared gas analyzer was used periodically to check the efficiency of the $\mathrm{CO}_{2}$ traps, which were found to quantitatively remove $\mathrm{CO}_{2}$ from the air stream. Teflon tubing connected the jars and the traps, and a second set of water-jacketed condensers removed monoethanolamine vapor from the air effluent from the $\mathrm{CO}_{2}$ traps. Dessicant columns in the system dried the air stream to prevent condensation in the tubing (Fig. 1).
Soil

The soil was an artificial sandy loam, made by mixing $\mathrm{Par}$ silt loam (fine-silty, mixed, mesic Calcic Argixeroll) with coentey washed sand at a ratio of $1: 2(w / w)$. The addition of sand to the silt loam was necessary in order to maintain adequate draine and aeration in our system. The silt loam (stored at $4{ }^{\circ} \mathrm{C} \approx 1$ ? before use) was obtained from the Utah State University Blue Creek Research Station, Box Elder County, Utah, from the top $15 \mathrm{~cm}$ of the soil profile. The sandy loam mixture (sand, 75\%; silt, $19 \%$; clay, $6 \%$; organic $\mathrm{C} 0.6 \% ; \mathrm{pH}=7.2 ; \mathrm{CEC}=6 \%$ $\mathrm{meq} / \mathrm{kg}$, field capacity $=10.1 \%$ gravimetric water) was loosely packed into plant holders (capacity $\approx 70 \mathrm{~g}$ soil), which were glass columns $(15$ by $2.8 \mathrm{~cm})$ fitted with scintered glass support disks Planted and unplanted soils were kept near field capacity by ad. dition of a nutrient solution, via a long syringe needle, through a watering port at the top of the bell jar. Accidental overwatering sometimes occurred, and the resulting leachate was collected in beakers and reapplied to the soil. Small amounts of leachate dried in the beakers, resulting in an accumulation of residue. The root-soil-leachate zone was protected from light to promote normal root growth, and to prevent photodegradation of $\mathrm{PCP}$ or phenanthrene (Engelhardt et al., 1986; Sims and Overcash, 1983).

\section{Plants}

Hycrest crested wheatgrass was developed by hybridizing A. cristatum (L.) Gaertn. with $A$. desertorum. Agropyron is grouped with wheat in the Triticeae tribe (Dewey, 1984). Hycrest is superior to its parental species in stand establishment, especially under drought and other stressful conditions (Asay et al., 1986; Montero and Jones, 1992). Under some growth conditions, the fibrous root systems of crested wheatgrass may extend 1.5 to $2 \mathrm{~m}$ below the surface of the soil. Seeds were obtained from Dr. Kevin B. Jensen, USDA-ARS, Forage and Range Research Laboratory, Utah State University, Logan, UT, and were soaked on moist filter paper for $\mathbf{2} \mathrm{d}$ prior to planting in the test system. At the beginning of a trial, 8 to 10 seeds were spread on the surface of the contaminated soil and covered with a few millimeters of fresh soil. Cylinders were replanted during the trial by sowing seeds in the stubble of the previous crop.

\section{Nutrient Solution}

Plants and soil controls were watered with a solution containing $5 \mathrm{mM} \mathrm{NH} \mathrm{NO}_{3}, 0.25 \mathrm{mM} \mathrm{KH}_{2} \mathrm{PO}_{4}, 0.5 \mathrm{mM} \mathrm{K}_{2} \mathrm{SO}_{4}$, and 5 $\mu M \mathrm{Fe} / \mathrm{EDDHA}$ (ethylenediamine-di(O-hydroxyphenylacetic acid)). The composition of the nutrient solution was based on the composition of the plant tissue $(4 \% \mathrm{~N}, 2 \% \mathrm{~K}$, and $0.3 \% \mathrm{P}$ on the basis of the dry weight of shoots) and on the ratio of photosynthesis to transpiration ( $2.5 \mathrm{~g}$ weight formed $\mathrm{kg}^{-1}$ water transpired; Bugbee and Salisbury, 1988).

\section{Test Chemical Additions to Soil}

$\left[9-{ }^{14} \mathrm{C}\right]$ Phenanthrene and $\left[\mathrm{UL}-{ }^{14} \mathrm{C}\right]$ pentachlorophenol were obtained from Sigma Chemical Company. The radiochemical purity of the $\left[{ }^{14} \mathrm{C}\right] \mathrm{PCP}$ was $\geqslant 96 \%$. An ethanolic solution of the ${ }^{14} \mathrm{C}$-labeled test chemical (mixed with unlabeled reagent grade test chemical) was added to a portion of soil, mixed thoroughly, and the ethanol was allowed to dry under a fume hood. This spiked soil was thoroughly mixed with a larger portion of uncontaminated soil $(1: 13, w / w)$. The final concentration of test chemical in the mixture was $\approx 100 \mathrm{mg} \mathrm{kg}^{-1}$ dry weight of soil (specific radioactivity $\approx 13 \mathrm{GBq} \mathrm{kg}^{-1}$ test chemical). The final mixtur was either stored at $-20^{\circ} \mathrm{C}$ for further analysis (combustion, see below) or packed into the plant holders for use in the flow through test system. 
1. Distribution and recovery of ${ }^{14} \mathrm{C}$-label derived from $\left[{ }^{14} \mathrm{C}\right] \mathrm{PCP}$. The data are percent of total ${ }^{14} \mathrm{C}$ initially added. $\dagger$

\begin{tabular}{|c|c|c|c|c|c|c|c|c|}
\hline \multirow{3}{*}{ Sample } & \multicolumn{8}{|c|}{ Compartment } \\
\hline & \multirow[b]{2}{*}{ Soil } & \multirow[b]{2}{*}{${ }^{14} \mathrm{CO}_{2}$} & \multirow[b]{2}{*}{ Leachate } & \multirow{2}{*}{$\begin{array}{l}\text { Volatile } \\
\text { organic }\end{array}$} & \multicolumn{2}{|c|}{ Plant tissue $\ddagger$} & \multirow{2}{*}{$\begin{array}{c}\text { Evapo- } \\
\text { transpirational } \\
\text { condensate§ }\end{array}$} & \multirow{2}{*}{$\begin{array}{c}\text { Total } \\
\text { recovery }\end{array}$} \\
\hline & & & & & Root fraction & Shoots & & \\
\hline & \multicolumn{8}{|c|}{ Unplanted soil } \\
\hline & 79.7 & 6.0 & 9.6 & $1 . \overline{6}$ & - & - & - & 96.9 \\
\hline & 84.8 & 6.5 & 10.2 & 1.5 & - & - & - & 103.0 \\
\hline & 58.3 & 6.5 & 21.4 & 1.3 & - & _- & - & $\begin{array}{r}10.0 \\
87.5\end{array}$ \\
\hline \multirow{3}{*}{${ }^{c}$ Mean \pm SD } & $74.3 \pm 14.1$ & $6.3 \pm 0.3$ & $13.7 \pm 6.6$ & $1.5 \pm 0.2$ & - & - & - & $95.8 \pm 7.8$ \\
\hline & \multicolumn{8}{|c|}{ Planted soil } \\
\hline & 36.7 & 26.9 & 1.7 & 1.6 & -20.5 & 10.0 & 0.4 & 97.8 \\
\hline & 30.3 & 19.7 & 4.0 & 2.4 & 17.5 & 22.0 & 0.5 & 96.4 \\
\hline & 25.0 & 19.7 & 0.5 & 0.3 & 25.8 & 12.5 & 0.4 & 84.2 \\
\hline${ }^{c}$ Mean \pm SD & $30.7 \pm 5.9$ & $22.1 \pm 4.2$ & $2.1 \pm 1.8$ & $1.4 \pm 1.1$ & $21.3 \pm 4.2$ & $14.8 \pm 6.3$ & $0.4 \pm 0.1$ & $92.8 \pm 7$. \\
\hline
\end{tabular}

+ Each system initially contained $7.1 \mathrm{mg}\left[{ }^{14} \mathrm{C}\right] \mathrm{PCP}\left(5.32 \times 10^{6} \mathrm{dpm} / 68.0 \mathrm{~g}\right.$ dry soil; $\left.104 \mathrm{mg} \mathrm{kg}{ }^{-1}\right)$.

The total ${ }^{14} \mathrm{C}$ found in the shoots was an accumulation of the radiolabel from several harvests (Table 2). The root fraction (dry weight $=6.6 \pm 0.7 \mathrm{~g}$ ) was $\$$ The total tissue and $5.1 \mathrm{~g}$ rhizosphere soil (Methods).

Cold traps were used to trap water vapor generated by the plants (Methods).

\section{Processing of Plant Tissue}

Shoots were cut off at soil level and pulverized in liquid $\mathrm{N}_{2}$ using a mortar and pestle. At the end of the trial, large roots were manually separated from soil, and small roots were separated by passing the soil through a $0.25-\mathrm{mm}$ sieve. Roots were also pulverized at $-70^{\circ} \mathrm{C}$. Since the roots were not washed, some rhizosphere soil was included in the root fraction (Table 1). Soil in the root fraction was differentiated from root tissue by combustion analysis, and by assuming that on a dry weight basis, the root tissue contained $8 \%$ ash, and the soil $99 \%$ ash. This analysis indicated that the root fraction contained $23 \%$ root tissue and $77 \%$ soil.

\section{Experimental Design}

The fates of ${ }^{14} \mathrm{C}$-labeled compounds (either PCP or phenanthrene) were compared in three unplanted and three planted flowthrough systems. The six systems ran simultaneously and thus two sets of triplicate data were generated per trial. Results are presented for single trials run with either $\left[{ }^{14} \mathrm{C}\right]$ phenanthrene or $\left[{ }^{4} \mathrm{C}\right] \mathrm{PCP}$. Radioactivity was measured in soil, $\mathrm{CO}_{2}$ (mineralization), leachate, plant tissue, and in volatile organic compounds. Radiolabel $\left({ }^{14} \mathrm{C}\right)$ was measured in the soil initially (to calculate the starting ${ }^{14} \mathrm{C}$-label per test system) and at the end of the trial. Mineralization was monitored for each of the six flow-through systems at intervals during the trial. Means and standard deviations were calculated for each set of triplicate data.

\section{Analysis}

The ${ }^{14} \mathrm{C}$-radiolabel in soil and plant tissue was determined by combusting samples in a Harvey Instrument Biological Oxidizer (R.J. Harvey Instrument Corp., Hillsdale, NJ), and analyzing the trapped ${ }^{14} \mathrm{CO}_{2}$ by scintillation counting. Polyurethane foam plugs were cut into pieces and analyzed by scintillation counting, using a cocktail (Beckman Ready-Safe, Beckman Instruments, Fullerton, CA) in which the plugs became translucent. anol and scintilline from the $\mathrm{CO}_{2}$ traps was mixed with methDried scintillation cocktail and analyzed for ${ }^{14} \mathrm{C}$-radiolabel. scraped material derived from leachate was dissolved and/or analyzed for the beakers, mixed with scintillation cocktail, and

\section{RESULTS}

\section{Biodegradation of $\left[{ }^{14} \mathrm{C}\right]$ Phenanthrene; System Check}

We conducted preliminary studies to check the flowthrough system for leaks as well as for other factors that might have resulted in shortfalls in the ${ }^{14} \mathrm{C}$ budget. A short term biodegradation experiment was done with $\left[{ }^{14} \mathrm{C}\right]$ phenanthrene, a compound rapidly degraded by our soil system. The radiolabeled PAH was added to both planted and unplanted soil at $100 \mathrm{mg} \mathrm{kg}^{-1}$ (for the planted system, seeds were sown on Day 1 of the trial). A plateau in the time course for mineralization occurred by Day 20 (Fig. 2). There was no statistically significant difference between the planted and unplanted systems, probably because during the rapid flush of mineralization the plants were still small and exerted a predictably limited rhizosphere effect in the soil. In terms of percent of the total ${ }^{14} \mathrm{C}$ initially added to each system $(2.66 \mu \mathrm{Ci})$ the following ${ }^{14} \mathrm{C}$ budget was obtained (means, $n=6 \pm 1 \mathrm{SD}$ ): soil $=28.5 \pm 2.3 \% ;{ }^{14} \mathrm{CO}_{2}=67.4 \pm 8.4 \%$; leachate $=0.5$ $\pm 0.2 \%$; volatile organic $=0.6 \pm 0.3 \%$. The planted systems contained, in addition, some ${ }^{14} \mathrm{C}$-label in the plant tissue (means, $n=3 \pm 1 \mathrm{SD}$ ): roots $=2.8 \pm 0.8 \%$; shoots $=2.6 \pm 0.2 \%$. The total recovery of ${ }^{14} \mathrm{C}$ for the planted system $(102.4 \%)$ was slightly higher than for the unplanted system $(97.0 \%)$. The good recovery of the radiolabeled C derived from phenanthrene suggested that long term biodegradation studies using the flow-through system would yield a satisfactory ${ }^{14} \mathrm{C}$-budget.

\section{Biodegradation of $\left[{ }^{14} \mathrm{C}\right] \mathrm{PCP}$}

During the 155-day trial, the ${ }^{14} \mathrm{C}$-label initially added to the soil as $\left[{ }^{14} \mathrm{C}\right] \mathrm{PCP}\left(100 \mathrm{mg} \mathrm{kg}{ }^{-1}\right.$ soil) was redistributed into the various compartments of the flow-through system (Table 1). By the end of the trial, less ${ }^{14} \mathrm{C}$-label remained in the soil in the planted systems $(30.7 \pm 5.9 \%)$ than in the unplanted systems $(74.3 \pm 14.1 \%)$. More mineralization occurred in the planted systems $(22.1 \pm 4.2 \%)$ than in the unplanted systems $(6.3 \pm 0.3 \%)$. After an ini- 


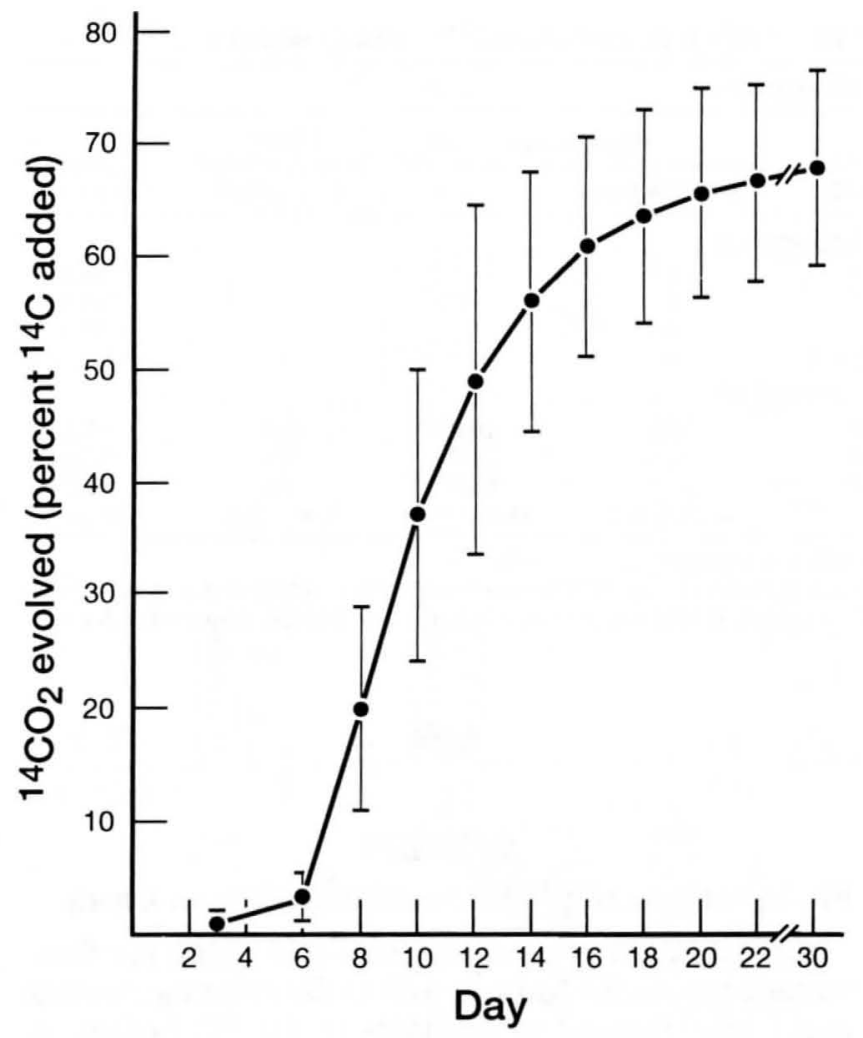

Fig. 2. Time course for the mineralization of $\left[{ }^{14} \mathrm{C}\right]$ phenanthrene. Data points are means, $n=6 \pm 1 \mathrm{SD}$. Data from the three planted and three unplanted systems were combined, since no significant difference was observed between the two types of systems (Methods).

tial lag period of $\approx 25 \mathrm{~d}$, the rate of mineralization in the planted systems was $\approx 3.5$ times faster than in the unplanted systems (Fig. 3). The mineralization data only partially reflect the increased rate of PCP degradation in the planted system. Depending on the microbial utilization efficiency for PCP, ${ }^{14} \mathrm{C}$-label would also have been incorporated to some extent into microbial biomass in the soil fraction. The soil fraction probably also contained ${ }^{14} \mathrm{C}$-label in the form of free and immobilized PCP-degradative intermediates. Less ${ }^{14} \mathrm{C}$-label was recovered as leachate from the planted $(2.1 \pm 1.8 \%)$ than from the unplanted $(13.7 \pm 6.6 \%)$ systems. Although accidental overwatering occurred during the trial for both types of systems (Methods), it seemed that the presence of a root mass or an increased rate of PCP degradation in the planted systems helped prevent the leaching of ${ }^{14} \mathrm{C}$-label. A total of $36 \%$ of the applied ${ }^{14} \mathrm{C}$ label was associated with the plant tissue, $21.3 \pm 4.2 \%$ in the root fraction and $14.8 \pm 6.3 \%$ in the shoots (Table 1 ).

At intervals during the trial, shoots were harvested and new plants were started from seed. The schedule for planting and harvesting is outlined in Table 2 . After $\approx 5 \mathrm{wk}$ of vigorous growth, the first crop of plants died, presumably due to PCP-toxicity. The dead shoots contained $9.0 \pm 3.9 \%$ of the total radiolabel and had a much higher bioconcentration factor (12.3) than the shoots harvested later (Table 2).

In addition to ${ }^{14} \mathrm{CO}_{2}$, other forms of volatilized ${ }^{14} \mathrm{C}$ radiolabel were recovered during the trial. Approximately $1.5 \%$ of the total ${ }^{14} \mathrm{C}$ was recovered in the volatile organic traps (Fig. 1, Methods), and this recovery was the same

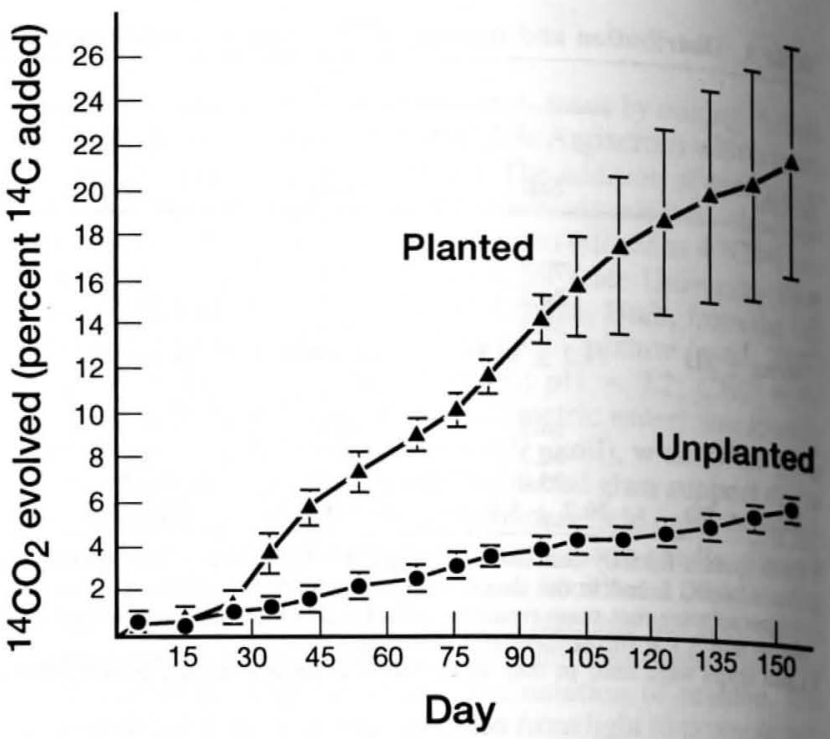

Fig. 3. Time course for the mineralization of $\left[{ }^{14} \mathrm{C}\right]$ pentachlorophenol. Results are shown for the unplanted and planted systems. The increase in the variance for the planted systems after Day 90 was due to an increased rate of mineralization for one of the systems (planted sy. tem $a$, Table 1) relative to the other two systems. The reason for thin increased rate is not known.

for both the unplanted and planted systems (Table 1). For the planted system, however, additional ${ }^{14} \mathrm{C}$-label $(0.4 \%$ of the total) was recovered in the cold traps, dissolved in the condensed transpirational water vapor.

\section{DISCUSSION}

The most striking difference between the planted and unplanted systems was the time course for the mineralization of $\left[{ }^{14} \mathrm{C}\right] \mathrm{PCP}$ (Fig. 3). In the planted system, a lag time followed by an increased rate may have been related to the period required for the establishment of a substantial plant rhizosphere. In the unplanted system, on the other hand, ${ }^{14} \mathrm{C}$-label was mineralized at a slow constant rate throughout the $155 \mathrm{~d}$ trial. Other workers have noted the stability of PCP in soil contaminated with comparable levels

Table 2. Uptake of ${ }^{14} \mathrm{C}$-radiolabel by plant shoots and calculation of the bioconcentration factor (BCF).

\begin{tabular}{lcccc}
\hline \multicolumn{2}{c}{ Harvest $\dagger$} & & & \\
\cline { 1 - 1 } No. & Day & Dry weight & ${ }^{14}$ C-Label & BCF \\
\hline & & $\mathrm{g}$ & dpm $\times 10^{6}$ & \\
1 & 41 & $0.5 \pm 0.2$ & $0.48 \pm 0.21$ & 12.3 \\
2 & 74 & $0.3 \pm 0.1$ & $0.03 \pm 0.02$ & 1.3 \\
3 & 89 & $0.4 \pm 0.2$ & $0.04 \pm 0.02$ & 1.3 \\
4 & 105 & $1.2 \pm 0.1$ & $0.17 \pm 0.06$ & 1.8 \\
5 & 137 & $0.5 \pm 0.1$ & $0.03 \pm 0.03$ & 0.8 \\
6 & 155 & $1.5 \pm 0.1$ & $0.04 \pm 0.02$ & 0.3 \\
\hline
\end{tabular}

† The crested wheatgrass plants grew rapidly and soon became too tall to fit in the bell jars. We therefore cut off the shoots a few centimeters above soil level at intervals during the trial. After the third such harvest, the rate of regeneration decreased and new plants were started from seed (Methods), but the root zone was not disturbed during the trial. Seeds were sown on Days 1, 37, and 105. The first crop of plants died (Harvest 1). Shoots were cut three times following the second planting (Harvests 2-4) and twice for lowing the third planting (Harvests 5 and 6 ).

$\ddagger$ BCF values were calculated by dividing ${ }^{14} \mathrm{C}$-radiolabel in the dry plant tis sue $\left(\mathrm{dpm} \mathrm{g}^{-1}\right)$ by the initial ${ }^{14} \mathrm{C}$ in the dry soil $\left(0.078 \times 10^{6} \mathrm{dpm} \mathrm{g}^{-1}\right)($ Beli and O'Connor, 1990). 
of the chemical (Middeldorp et al., 1990). Seech et al. (1991) reported that for a silt loam soil containing $175 \mathrm{mg}$ $P C P \mathrm{~kg}^{-1},<1 \%$ mineralization occurred during a $210 \mathrm{~d}$ trial. The stability of the compound is understandable, since high concentrations of PCP are toxic to many bacteria Klecka and Maier, 1985; Ruckdeschel et al., 1987; Yokoyama et al., 1988) and certain fungi (Lamar et al., $1990 \mathrm{~b}$ ), which are principally responsible for the biodegradation of PCP in soil. At a concentration of $200 \mathrm{mg} \mathrm{kg}^{-1}$, PCP has been reported to completely inhibit $\mathrm{O}_{2}$ uptake by soil (Hicks et al., 1990). In the planted systems, however, the increased rate of mineralization was probably due to microbial catabolism, since plants do not appear to actively mineralize PCP (Sandermann et al., 1984), and it is unlikely that abiotic processes could have resulted in mineralization (Cork and Krueger, 1991).

A trivial explanation of the increased rate of mineralization in the planted system is that additional organic matter, in the form of root exudates, accelerated microbial degradation of PCP. The stimulatory effect of soil organic matter on PCP transformation has been observed (Kuwatsuka and Igarashi, 1975; Middeldorp et al., 1990; Seech et al., 1991). In none of these cases, however, was an increased rate of mineralization observed. Middeldorp et al. (1990) cautioned, in fact, that simple addition of organic matter to soil in order to stimulate PCP bioremediation may accelerate the conversion of PCP to lipophilic compounds (such as pentachloroanisol), which have an increased potential to bioaccumulate.

Other hypotheses to explain our mineralization data are based on the idea that plants have highly specific effects on soil microflora. A variety of studies have shown that rhizosphere soil itself, with plants removed, had an increased biodegradative potential compared to nonvegetated soil. Walton and Anderson (1990) reported accelerated mineralization of trichloroethylene in rhizosphere soil, and Sandmann and Loos (1984) observed as much as 100-fold more 2,3-dichlorophenoxyacetate-degrading organisms in rhizosphere soil as compared with unplanted soil. These results suggest that plants may encourage microorganisms with broad metabolic capabilities.

Radiolabel in the shoots (Table 1 and 2) probably resulted from translocation of ${ }^{14} \mathrm{C}$-labeled material taken up from the soil by the roots. Photosynthetic fixation of ${ }^{14} \mathrm{CO}_{2}$ emanating from the soil via mineralization, or foliar uptake of ${ }^{14} \mathrm{C}$-labeled volatile organic material (Topp et al., 1986), were probably not significant sources of radiolabel in the shoots. Calculations based on the flux of air through the flow-through system ( $1 \mathrm{~L} \mathrm{~min}^{-1}$, Methods) and the resulting dilution of the ${ }^{14} \mathrm{CO}_{2}$ by unlabeled $\mathrm{CO}_{2}$ in the air stream indicated that no measurable radiolabel in the shoots could have originated from ${ }^{14} \mathrm{CO}_{2}$ fixation. Foliar uptake of volatile organic label can also be ruled out. Several studies have shown that volatilization of PCP or its metabolites from soil even after several months is negligible (Kloskowski et al., 1981; Lamar et al., 1990a). This low volatility, coupled with the flux of air through the test system, would minimize foliar uptake. Our value of $1.5 \%$ of the total ${ }^{14} \mathrm{C}$-label trapped as volatile organic material after $155 \mathrm{~d}$ (Table 1) was compatible with the report of Lamar et al. (1990a). These workers added $\left[{ }^{14} \mathrm{C}\right] \mathrm{PCP}$ to a sandy loam at a concentration of $50 \mathrm{mg} \mathrm{kg}^{-1}$ soil, and recovered only 0.2 to $0.3 \%$ of the applied radiolabel as volatile organic material (using traps containing 2-methoxyethanol) after a two month trial.

The extent of uptake of ${ }^{14} \mathrm{C}$-label by the shoots from the six harvests was compared in terms of the bioconcentration factor (BCF; Table 2). Values for BCF were calculated by dividing the concentration of ${ }^{14} \mathrm{C}$-label in the dry plant tissue $\left(\mathrm{dpm}^{-1}\right)$ by that initially present in the dry soil (Bellin and O'Connor, 1990). The first crop of plants, which died after a period of vigorous growth, yielded shoots with BCF values of 6.8 to 40 -fold higher than shoots from later harvests (Harvest no. $1, \mathrm{BCF}=12.3)$. $\mathrm{BCF}$ values for shoots from harvests 2 through 6 (mean $=1.1 \pm 0.6$ ) were similar to those reported by Bellin and O'Connor (1990) for the uptake of radiolabel by tall fescue (Festuca arundinacea Schreb.) growing in a sandy loam containing relatively low levels of $\left[{ }^{14} \mathrm{C}\right] \mathrm{PCP}\left(5 \mathrm{mg} \mathrm{PCP} \mathrm{kg}^{-1}\right.$ soil; $\mathrm{BCF}=1.5-2.3$ ). The basis for the decreased $\mathrm{BCF}$ and phytotoxicity in the later harvests may have been PCP degradation. The degradative products may have been less available for plant uptake and less phytotoxic than the parent compound. Alternatively, the decreased BCF and toxicity may have resulted in part from the $\left[{ }^{14} \mathrm{C}\right] \mathrm{PCP}$ itself becoming less available for plant uptake, due to processes such as sorption onto soil organic matter or to physical sequestering.

Our results indicate that vegetation may be beneficial when planted in soil contaminated with PCP. By the end of the trial, the soil in the planted systems had lower levels of PCP-derived material than did the controls, as a result of increased mineralization (Fig. 3) and plant uptake (Table 1 and 2). Furthermore, plant transpiration may induce the mass transport of compounds dissolved in the soil water toward the root. Thus, unsaturated flow may draw PCP and its metabolites to the plants from outside the root zone, thereby making them available for removal from soil. A serious question which remains, however, is the possible toxicity to herbivores of vegetation planted on PCP-contaminated soil, and the resulting contamination of the food chain. Among the predominant products of PCP-catabolism, both in soil microorganisms and in plant cell culture, are tetrachloro-derivatives of catechol and hydroquinone. These compounds are known to cause DNA damage (Witte et al., 1985; Van Ommen et al., 1986). The data of Langebartels and Harms (1985) suggested that these potential mutagens accumulated in whole plants. Wheat plants grown in reportedly aseptic nutrient solution that contained $\left[{ }^{14} \mathrm{C}\right] \mathrm{PCP}$ incorporated radiolabel mainly into insoluble cell wall components such as lignin and hemicellulose. Subsequent analysis of these components indicated that tetrachlorocatechol was the predominant PCP metabolite (Schäfer and Sanderman, 1988). Digestion of an insoluble fraction with hemicellulase liberated $\left[{ }^{14} \mathrm{C}\right] \mathrm{PCP}$ and its metabolites, suggesting that toxic compounds may be bioavailable in the gut of an animal (Langebartels and Harms, 1985).

Future research may explore the feasibility of using white rot fungus to degrade the PCP-derived compounds which accumulate in plant tissue. Phanerochaete chrysosporium Burdsall in Burdsall \& Eslyn is known to mineralize PCP 
(Mileski et al., 1988) as well as the lignin and hemicellulose in ligno-cellulosic complexes (Kirk and Farrell, 1987). The fungus also liberated ${ }^{14} \mathrm{CO}_{2}$ from an enzymatically prepared $\left[{ }^{14} \mathrm{C}\right]$ tetrachloroquinone-lignin copolymer (Schäfer and Sandermann, 1988). A possible scheme for the bioremediation of PCP contaminated soil may therefore involve a two-step process. The PCP-derived material, which is drawn to and accumulates in vegetation planted on contaminated soil, could be further degraded in a second treatment step, in which the contaminated plant material is used as mulch to support fungal growth.

\section{ACKNOWLEDGMENTS}

Liliane Stacishin provided excellent technical assistance and Gus Koerner helped in the design of the flow-through system. We thank B.M. Olivera for providing support for the preparation of the manuscript, and Nancy Kurtzeborn for her skillful typing. We also thank Roy C. Sidle and Jenny Norton for reviewing the manuscript and for their helpful comments.

\section{REFERENCES}

Aprill, W., and R.C. Sims. 1990. Evaluation of the use of prairie grasses for stimulating polycyclic aromatic hydrocarbon treatment in soil. Chemosphere 20:253-265.

Asay, K.H., D.R. Dewey, F.B. Gomm, W.H. Horton, and K.B. Jensen. 1986. Genetic progress through hybridization of induced and natural tetraploids in Crested Wheatgrass. J. Range Manage. 39:261-263.

Bellin, C.A., and G.A. O'Connor. 1990. Plant uptake of pentachlorophenol from sludge-amended soils. J. Environ. Qual. 19: 598-602.

Bellin, C.A., G.A. O'Connor, and Y. Jin. 1990. Sorption and degradation of pentachlorophenol in sludge-amended soils. J. Environ. Qual. 19:603-608.

Briggs, G.G., R.H. Bromilow, and A.V. Evans. 1982. Relationships between lipophilicity and root uptake and translocation of non-ionized chemicals by barley. Pestic. Sci. 13:495-504.

Bugbee, B.G., and F.B. Salisbury. 1988. Exploring the limits of crop productivity: I. Photosynthetic efficacy of wheat in high irradiance environments. Plant Physiol. 88:869-878.

Casterline, J.L., Jr., N.M. Barnett, and Y. Ku. 1985. Uptake, translocation and transformation of pentachlorophenol in soybean and spinach plants. Environ. Res. 37:101-118.

Cork, D.J., and J.P. Krueger. 1991. Microbial transformations of herbicides and pesticides. Adv. App. Microbiol. 35:1-66.

Crawford, R.L., and W.W. Mohn. 1985. Microbiological removal of pentachlorophenol from soil using a Flavobacterium. Enzyme Microb. Technol. 7:617-620.

Dewey, D.R. 1984. The genomic system of classification as a guide to intergeneric hybridization with the perennial Tritceae. p. 209-279. In J.P. Gustafson (ed.) Gene manipulation in plant improvement. Plenum Publ. Corp., New York.

Edgehill, R.U., and R.K. Finn. 1983. Microbial treatment of soil to remove pentachlorophenol. Appl. Environ. Microbiol. 45:1122-1125.

Edwards, N.T. 1986. Uptake, translocation and metabolism of anthracene in bush bean (Phaseolus vulgaris L.). Environ. Toxicol. Chem. 5:659-665.

Engelhardt, G., P.R. Wallnöfer, W. Mücke, and G. Renner. 1986. Transformation of pentachlorophenol: II. Transformations under environmental conditions. Toxicol. Environ. Chem. 11:233-252.

Federle, T.W., and B.S. Schwab. 1989. Mineralization of surfactants by microbiota of aquatic plants. Appl. Environ. Microbiol. 55:20922094.

Haque, A., I. Scheunert, and F. Korte. 1978. Isolation and identification of a metabolite of pentachlorophenol- ${ }^{14} \mathrm{C}$ in rice plants. Chemosphere 1:65-69.

Harms, H., and C. Langebartels. 1986. Standardized plant cell suspension test systems for an ecotoxicologic evaluation of the metabolic fate of xenobiotics. Plant Sci. 45:157-165.

Hicks, R.J., G. Stotzky, and P. Van Voris. 1990. Review and evaluation of the effects of xenobiotic chemicals on microorganisms in soil. Adv.
Appl. Microbiol. 35:195-253.

Hsu, T.-S., and R. Bartha. 1979. Accelerated mineralization of ganophosphate insecticides in the rhizosphere. Appl. Environ. Mi. crobiol. 37:36-41.

Huckins, J.N., J.D. Petty, and M.A. Heitkamp. 1984. Modula tainers for microcosm and process model studies on the fate and effiex of aquatic contaminants. Chemosphere 12:1329-1341.

Johnson, R.L., S.M. Brillante, L.M. Isabelle, J.E. Houck, and J.F Pankow. 1985. Migration of chlorophenolic compounds at the chemica waste disposal site at Alkali Lake, Oregon: 2. Contaminant distribo. tions, transport, and retardation. Ground Water 23:652-666.

Kaiser, K.L.E., and Valdmanis, I. 1982. Apparent octanol/water tion coefficients of pentachlorophenol as a function of $\mathrm{pH}$. Can. J Chem. 60:2104-2106.

Kirk, T.K., and R.L. Farrell. 1987. Enzymatic "combustion": The microbial degradation of lignin. Annu. Rev. Microbiol. 41:465-505.

Kitunen, V.H., R.J. Valo, and M.S. Salkinoja-Salonen. 1987. Con nation of soil around wood-preserving facilities by polych aromatic compounds. Environ. Sci. Technol. 21:96-101.

Klecka, G.M., and W.J. Maier. 1985. Kinetics of microbial g pentachlorophenol. Appl. Environ. Microbiol. 49:46-53.

Kloskowski, R., I. Scheunert, W. Klein, and F. Korte. 1981. Labon tory screening of distribution, conversion and mineralization of chemicals in the soil-plant-system and comparison to outdoor experimental data. Chemosphere 10:1089-1100.

Kuwatsuka, S., and M. Igarashi. 1975. Degradation of PCP in II. The relationship between the degradation of $\mathrm{PCP}$ and the ties of soils, and the identification of the degradation products of $P C P$ Soil Sci. Plant Nutr. (Tokyo) 21:405-414.

Lamar, R.T., J.A. Glasser, and T.K. Kirk. 1990a. Fate of penta. chlorophenol (PCP) in sterile soils inoculated with the white-rot basidomycete Phanerochaete chrysosporium: mineralization, volatilization and depletion of PCP. Soil Biol. Biochem. 22:433-440.

Lamar, R.T., M.J. Larsen, and T.K. Kirk. 1990b. Sensitivity to degradation of pentachlorophenol by Phanerochaete spp. Appl. Environ. Microbiol. 56:3519-3526.

Langebartels, C., and H. Harms. 1985. Analysis for nonextractable (bound) residues of pentachlorophenol in plant cells using a cell wall fractionation procedure. Ectotoxicol. Environ. Saf. 10:268-279.

Lappin, H.M., M. P. Greaves, and J.H. Slater. 1985. Degradation of the herbicide mecoprop [2-(2-methyl-4-chlorophenoxy)propionic acid] by a synergistic microbial community. Appl. Environ. Microbiol. 49:429-433.

Lynch, J.M. 1982. Interactions between bacteria and plants in the root environment. p. 1-23. In M.E. Rhodes-Roberts and F.A. Skinner (ed.) Bacteria and plants. Society of Applied Bacteriology Symposium So ries no. 10. Academic Press, London.

McFarlane, J.C., T. Pfleeger, and J. Fletcher. 1987. Transpiration effect on the uptake and distribution of bromacil, nitrobenzene, and phe nol in soybean plants. J. Environ. Qual. 16:372-376.

Middeldorp, P.J.M., M. Briglia, and M.S. Salkinoja-Salonen. 1990 Biodegradation of pentachlorophenol in natural soil by inoculated Rhodococcus chlorophenolicus. Microb. Ecol. 20:123-139.

Mileski, G.J., J.A. Bumpus, M.A. Jurek, and S.D. Aust. 1988. Biodegradation of pentachlorophenol by the white rot fungus Phanerochad chrysoporium. Appl. Environ. Microbiol. 54:2885-2889.

Montero, C.M., and T.A. Jones. 1992. Establishment of 'Hycrest' crested and T-21076 thickspike wheatgrasses in three environments. Crop Sci. 32:1016-1020.

Rao, K.R. (ed). 1978. Pentachlorophenol. Chemistry, pharmacology, and environmental toxicology. Plenum Press, New York.

Ravanel, P., and M. Tissut. 1986. Toxicity of pentachlorophenol on isclated plant mitochondria. Phytochemistry 25:577-583.

Reddy, B.R., and N. Sethunathan. 1983. Mineralization of parathio in the rice rhizosphere. Appl. Environ. Microbiol. 45:826-829.

Rovira, A.D., and C.B. Davey. 1974. Biology of the rhizosphere. P 153-204. In E.W. Carson (ed.) The plant root and its environ

University Press of Virginia, Charlottesville.
Ruckdeschel, G., G. Renner, and K. Schwarz. 1987. Effects of pentschlorophenol and some of its known and possible metabolites on difies ent species of bacteria. Appl. Environ. Microbiol. 53:2689-2692

Ryan, J.A., R.M. Bell, J.M. Davidson, and G.A. O'Connor. 1988. Plante uptake of non-ionic organic chemicals from soils. Chemospto 17:2299-2323.

Sandermann, H., Jr., D. Scheel, and Th.V.D. Trenck. 1984. Use of plas 
cell cultures to study the metabolism of environmental chemicals. Ecotoxicol. Environ. Saf. 8:167-182.

E.R.I.C., and M.A. Loos. 1984. Enumeration of 2,4-Dundmanding microorganisms in soils and crop plant rhizospheres using degrador media; high populations associated with sugarcane (Saccharium officinarum). Chemosphere 13:1073-1084.

charium and H. Sandermann, Jr. 1988. Metabolism of pentaschäfer, W., and in cell suspension cultures of wheat (Triticum aestichior. Tetrachlorocatechol as a primary metabolite. J. Agric. Food Chem. 36:370-377.

Cheel, D., W. Schäfer, and H. Sandermann Jr. 1984. Metabolism of pentachlorophenol in cell suspension cultures of soybean (Glycine max L.) and wheat (Triticum aestivum L.). General results and isomation of lignin metabolites. J. Agric. Food Chem. 32:1237-1241. scheunert, I., Z. Qiao, and F. Korte. 1986. Comparative studies of the fate of atrazine $-{ }^{14} \mathrm{C}$ and pentachlorophenol- $-{ }^{14} \mathrm{C}$ in various laboratory and outdoor soil-plant systems. Environ. Sci. Health B21:457-485.

Schmitt, R., J. Kaul, Th.V.D. Trenck, E. Schaller, and H. Sandermann Jr. 1985. $\beta$-D-Glucosyl and O-malonyl- $\beta$-D-glucosyl conjugates of pentachlorophenol in soybean and wheat: Identification and enzymentic synthesis. Pestic. Biochem. Physiol. 24:77-85.

Schellenberg, K., C. Leuenberger, and R.P. Schwarzenbach. 1984. Sorption of chlorinated phenols by natural sediments and aquifer materials. Environ. Sci. Technol. 18:652-657.

Seech, A.G., J.T. Trevors, and T.L. Bulman. 1991. Biodegradation of pentachlorophenol in soil: The response to physical, chemical and biological treatments. Can. J. Microbiol. 37:440-444.

Sims, R.C., and M.R. Overcash. 1983. Fate of polynuclear aromatic compounds (PNAs) in soil-plant systems. Residue Rev. 88:2-68.

Sittig, M. 1981. Handbook of toxic and hazardous chemicals. Noyes
Publ. Park Ridge, New Jersey.

Steiert, J.G., and R.L. Crawford. 1985. Microbial degradation of chlorinated phenols. Trends Biotech. 3:300-305.

Stroo, H.F. 1992. Biotechnology and hazardous waste treatment. J. Environ. Qual. 21:167-175.

Topp, E., I. Scheunert, A. Attar, and F. Korte. 1986. Factors affecting the uptake of ${ }^{14} \mathrm{C}$-labeled organic chemicals by plants from soil. Ecotoxicol. Environ. Saf. 11:219-228.

Valo, R., V. Kitunen, M. Salkinoja-Salonen, and S. Räisänen. 1984. Chlorinated phenols as contaminants of soil and water in the vicinity of two Finnish sawmills. Chemosphere 13:835-844.

Van Ommen, B., A. Adang, F. Müller, and P.J. Van Bladeren. 1986. The microsomal metabolism of pentachlorophenol and its covalent binding to protein and DNA. Chem. Biol. Interact. 60:1-11.

Walton, B.T., and T.A. Anderson. 1990. Microbial degradation of trichloroethylene in the rhizosphere: Potential application to biological remediation of waste sites. Appl. Environ. Microbiol. 56: 1012-1016.

Weiss, U.M., P. Moza, I. Scheunert, A. Haque, and F. Korte. 1982. Fate of pentachlorophenol- ${ }^{14} \mathrm{C}$ in rice plants under controlled conditions. J. Agric. Food Chem. 30:1186-1190.

Whipps, J.M., and J.M. Lynch. 1986. The influence of the rhizosphere on crop productivity. Adv. Microb. Ecol. 9:187-244.

Witte, I., U. Juhl, and W. Butte. 1985. DNA-damaging properties and cytotoxicity in human fibroblasts of tetrachlorohydroquinone, a pentachlorophenol metabolite. Mutation Res. 145:71-75.

Yokoyama, M.T., K.A. Johnson, and J. Gierzak. 1988. Sensitivity of ruminal microorganisms to pentachlorophenol. Appl. Environ. Microbiol. 54:2619-2624.

\title{
Organic Chemicals in the Environment
}

\section{Monitoring for Selected Degradation Products following a Spill of VAPAM into the Sacramento River}

\author{
Aurora del Rosario,* John Remoy, Violeta Soliman, Joginder Dhaliwal, Jagdev Dhoot, and Kusum Perera
}

\begin{abstract}
Following a rail accident that spilled the soil fumigant VAPAM into the Sacramento River on 14 July 1991, a special study was carried out to assess the extent of contamination in Lake Shasta. A total of 32 river water samples collected on 18 July and another 316 samples collected from 22 July through 30 August were analyzed. Data obtained clearly showed the presence of the degradation products of Metham, namely, methyl isothiocyanate, carbonyl sulfide, methyl sulfide, and traces of methylamine. However, due to the emergency nature of the incident that required quick analytical turnaround times, as well as the unavailability of a satisfactory analytical method, the presence of Metham could tory's demonstrated with certainty initially. Nonetheless, the laboratory's timely response to the crisis assisted public health officials in assessing the extent of the contamination and assuring the communityat-large that their drinking water was safe to consume. None of the degradation products analyzed were detected 1 wk after the spill.
\end{abstract} N 14 July 1991, the soil fumigant VAPAM spilled into California's Sacramento River from a derailed SouthSanitation and Radiation Laboratory, Division of Laboratories, California "Corresponding alth Services, Berkeley, CA 94704. Received 24 Nov. 1992. Publ ablished in J. Environ. Qual. 23:279-286 (1994). ern Pacific Railroad train at a railroad crossing called the Cantara Loop located $48 \mathrm{~km}$ upstream from Lake Shasta (Fig. 1).

VAPAM (ICI Americas International, Wilmington, DE) is the commercial product formulated with $32.7 \%$ solution of the active ingredient, metham (Weed Science Society of America, 1989, p. 176-177) and its chemical name, sodium methyl dithiocarbamate (ICI Americas International) shall be referred to as Na-MDTC when its chemistry is involved. VAPAM is a fumigant with fungicidal, nematocidal, and herbicidal action. Its pesticidal activity is due to methyl isothiocyanate (MITC); water solubility of the salt (Na-MDTC) at $20^{\circ} \mathrm{C}$ is $722 \mathrm{~g} \mathrm{~L}^{-1}$, while that of MITC is $7.6 \mathrm{~g} \mathrm{~L}^{-1}$ (WSSA, 1989). The environmental fate of metham is documented (Royal Soc. of Chem., 1990; Fukuto and Sims, 1971; WSSA, 1989; Hazardous Substances Data Bank, 1991; Kaufman, 1967). However, information of its fate in flowing water such as in a spill is nil.

Abbreviations: MITC, methyl isothiocyanate; SRL, Sanitation and Radiation Laboratory; CDHS, California State Department of Health Services; RWQCB, Regional Water Quality Control Board; ODW, Office of Drinking Water; HPLC, high performance liquid chromatography; GC/MS, gas chromatography/mass spectrometry; AEL, American Environmental Laboratory. 